\title{
Lubrication performance of an ammonium cation-based ionic liquid used as an additive in a polar oil
}

\author{
J.L. Viesca ${ }^{\mathrm{a}, \mathrm{d}}$, M.T. Mallada ${ }^{\mathrm{b}}$, D. Blanco ${ }^{\mathrm{a}}$, A. Fernández-González \\ J. Espina-Casado ${ }^{c}$, R. González ${ }^{\mathrm{b}, \mathrm{d}}$, A. Hernández Battez ${ }^{\mathrm{a}, \mathrm{d}^{*}}$ \\ ${ }^{a}$ Department of Construction and Manufacturing Engineering, University of Oviedo, Asturias, Spain \\ ${ }^{\mathrm{b}}$ Department of Marine Science and Technology, University of Oviedo, Asturias, Spain \\ ${ }^{c}$ Department of Physical and Analytical Chemistry, University of Oviedo, Asturias, Spain \\ ${ }^{\mathrm{d}}$ Department of Design and Engineering, Bournemouth University, Poole, BH12 5BB, UK \\ (*) Email: $\underline{\text { aehernandez@ uniovi.es }}$
}

\begin{abstract}
This paper studies the tribological behavior of the ionic liquid methyltrioctylammonium bis(trifluoromethylsulfonyl)imide $\left(\left[\mathrm{N}_{1888}\right]\left[\mathrm{NTf}_{2}\right]\right)$ as additive at different concentrations $(1.25,2.50,3.75$ and $5.00 \mathrm{wt} \%$ ) in a polar base oil (diester). A tribometer using a ball-on-disk reciprocating configuration under fully flooded lubrication was used at a frequency of $15 \mathrm{~Hz}$, at three different loads (40, 80 and 120 $\mathrm{N}$ ), stroke length of $4 \mathrm{~mm}$, and duration of 45 minutes. Worn surface on the disk was studied by confocal microscopy, SEM and XPS. Main results showed similar coefficient of friction for all lubricant samples; but different wear results were found at different loads, probably related with the chemical states found for fluorine on the worn surface and the temperature-dependent adsorption-desorption processes.
\end{abstract}

Keywords: ionic liquid, polar oil, additive, lubrication

\section{Introduction}

Ionic liquids (ILs) are molten salts consisting in cations and anions, which have excellent physicochemical properties (inherent polarity, high thermal stability, low flammability, large liquid range, high viscosity and low melting point) for using them in lubrication. The use of ILs in lubrication was explored for the first time in 2001 [1] and the attention in this subject has increased greatly over the years [2-6]. Many studies about the use of ILs as neat lubricant have showed their potential for lubricating different material pairs [7-18]. Despite the advantages of both physicochemical properties and tribological performance of the ILs, the use of them as neat lubricant or lubricant base stock is not economically feasible due to their high costs.

Due to their high costs, the feasibility of using ILs as lubricant additive has become in a prominent research topic. However, most of ILs are immiscible $(\ll<1 \%$ of solubility) in common nonpolar oils because the nonpolar neutral molecules are attracted by van der Waals forces while ions are held together by ionic forces and occasionally also by hydrogen bonding [6]. Several studies have been published using ILs as component of oil-IL emulsions or blended at low concentrations in nonpolar oils [8, 13, 19-36]. Meanwhile some authors used polar base oils seeking higher solubility with ILs [33, 37-51]. On the other hand, only few works have used ILs as an additive in fully-formulated oils [27, 34, 52-55] but more 
studies are necessary in order to know the compatibility of the ILs with other surface-adsorbing additives [6].

The first cations studied for tribological purpose were imidazolium-, ammonium-, pyrrolidinium-, pyridinium-, thiouronium-, and thiazolium-based. Meanwhile, anions such as $\left[\mathrm{BF}_{4}\right]^{-},\left[\mathrm{PF}_{6}\right]^{-},[\mathrm{Cl}]^{-}$, $\left[\mathrm{NTf}_{2}\right]^{-}$, [sulfate $]^{-}$and [sulfonate $]^{-}$were also explored first [6]. However, the main problems presented by these ILs were corrosion due to the hydrolysis of the anion and low solubility in nonpolar oils. Qu et al. reported trihexyltetradecylphosphonium bis(2-ethylhexyl) phosphate $\left(\left[\mathrm{P}_{6,6,6,14}\right][\mathrm{DEHP}]\right)$ and trihexyltetradecylphosphonium bis- (2,4,4-trimethylpentyl)alkylphosphinate $\left(\left[\mathrm{P}_{6,6,6,14}\right]-[\mathrm{BTMPP}]\right)$ as the first oil-soluble ILs [27, 52], which comprise quaternary structures with relatively long hydrocarbon chains both in cations and anions. From these two works emerged a theory, which state that an IL can be soluble in nonpolar oil if both cation and anion are also soluble.

With regard to the expected solubility of the ionic liquid in polar oils, ILs comprising cations such as imidazolium and pyrrolidinium; paired with many anions have resulted soluble in rapeseed oil, poly(ethylene glycol) (PEG), trimethylolpropane (TMP) oleate, castor oil, and glycerol, or in fullyformulated oils due to synergies with other additives [6]. From a tribological point of view, the possible interference between polar base oils and ILs used as additive in their interaction with metallic surfaces can affect friction and wear results. This paper studies the lubrication performance of an IL based on an ammonium cation and the $\left[\mathrm{NTf}_{2}\right]$ anion used as an additive at different concentrations in a polar oil.

\section{Experimental details}

\subsection{Lubricant samples preparation}

The ionic liquid methyltrioctylammonium bis(trifluoromethylsulfonyl)imide $\left(\left[\mathrm{N}_{1888}\right]\left[\mathrm{NTf}_{2}\right]\right)$ was used as lubricant additive to a biodegradable diester with high oxidative and hydrolytical stability. The ammonium-based IL was provided by Io-Li-Tec (Ionic Liquid Technologies GmbH) and the polar base oil (Priolube 1936) was kindly supplied by CRODA, S.A. A description of the main properties of these compounds is shown in Table 1. IL-containing mixtures were prepared with the base oil and concentrations of $1.25,2.50,3.75$ and $5.00 \mathrm{wt} \%$ of the IL. The solubility of the $\left[\mathrm{N}_{1888}\right]\left[\mathrm{NTf}_{2}\right]$ in the polar oil used in this work was tested using the turbidimetry technique and results showed that the IL is miscible in the oil at least $30 \mathrm{wt} \%$. The corrosion activity of the IL on different substrates (steel, TiN, $\mathrm{CrN}, \mathrm{ZrN}$ ) was tested before [56] and no evidence of corrosion was found on these materials. 
Table 1. Material properties.

\begin{tabular}{|c|c|c|c|c|c|c|}
\hline \multicolumn{3}{|c|}{$\begin{array}{l}\text { IUPAC NAME } \\
\text { (CAS NUMBER) }\end{array}$} & Purity (\%) & $\begin{array}{l}\text { Density } \\
20^{\circ} \mathrm{C} \\
\left(\mathrm{g} / \mathrm{cm}^{3}\right)\end{array}$ & $\begin{array}{c}\text { Mol. } \\
\text { Weight }\end{array}$ & $\begin{array}{l}\text { Viscosity } \\
40^{\circ} \mathrm{C} \\
(\mathrm{mPa} \cdot \mathrm{s})\end{array}$ \\
\hline \multicolumn{3}{|c|}{$\begin{array}{c}\text { Methyltrioctylammonium } \\
\text { bis(trifluoromethylsulfonyl)imide } \\
(375395-33-8)\end{array}$} & 99 & 1.109 & 648.85 & 200.7 \\
\hline \multicolumn{7}{|c|}{ Chemical structure } \\
\hline \multicolumn{3}{|c|}{ Cation } & \multicolumn{4}{|c|}{ Anion } \\
\hline \multicolumn{3}{|c|}{$\mathrm{C}_{25} \mathrm{H}_{54} \mathrm{~N}^{+}$} & \multicolumn{3}{|c|}{$\mathrm{C}_{2} \mathrm{~F}_{6} \mathrm{~S}_{2} \mathrm{O}_{4} \mathrm{~N}^{-}$} & \\
\hline \multicolumn{3}{|c|}{$\begin{array}{c}\mathrm{CH}_{2}\left(\mathrm{CH}_{2}\right)_{6} \mathrm{CH}_{3} \\
\mathrm{H}_{3} \mathrm{C}-\mathrm{N}^{+}-\mathrm{CH}_{2}\left(\mathrm{CH}_{2}\right)_{6} \mathrm{CH}_{3} \\
\mathrm{CH}_{2}\left(\mathrm{CH}_{2}\right)_{6} \mathrm{CH}_{3}\end{array}$} & & & & \\
\hline \multicolumn{3}{|c|}{$\left[\mathrm{N}_{1888}\right]$} & \multicolumn{4}{|c|}{$\left[\mathrm{NTf}_{2}\right]$} \\
\hline \multirow[t]{2}{*}{ Name } & \multirow[t]{2}{*}{ Oil type } & \multirow{2}{*}{$\begin{array}{l}\text { Density } \\
20^{\circ} \mathrm{C} \\
\left(\mathrm{g} / \mathrm{cm}^{3}\right)\end{array}$} & \multirow{2}{*}{$\begin{array}{c}\text { Viscosity } \\
\text { Index } \\
\text { ASTM D 2270 }\end{array}$} & \multicolumn{3}{|c|}{$\begin{array}{c}\text { Viscosity }(\mathrm{mPa} \cdot \mathrm{s}) \\
\text { ASTM D } 445 \\
\end{array}$} \\
\hline & & & & & & $100^{\circ} \mathrm{C}$ \\
\hline $\begin{array}{l}\text { Priolube } 1936 \\
\text { (coded as A2) }\end{array}$ & $\begin{array}{l}\text { Petrochemical } \\
\text { diester }\end{array}$ & 0.91 & 139 & & & 5.3 \\
\hline
\end{tabular}

\subsection{Friction and wear tests}

A Bruker UMT-3 micro-tribometer with a reciprocating ball-on-disk configuration was used for friction and wear testing. The tribological tests were performed for a period of 45 minutes under normal loads of 40, 80 and $120 \mathrm{~N}$ (corresponding to maximum contact pressures of 1.67, 2.10 and 2.41 GPa, respectively), with a stroke length of $4 \mathrm{~mm}$ and a frequency of $15 \mathrm{~Hz}$. Each test condition was repeated at least three times at room temperature using $4 \mathrm{ml}$ of lubricant sample in order to ensure fully flooded lubrication condition. Commercially available AISI 52100 chrome steel balls $(\varnothing 9.5 \mathrm{~mm}$, hardness 63 $\mathrm{HRC}, \mathrm{Ra} \leq 0.01 \mu \mathrm{m})$ were used as upper specimen and run against AISI 52100 steel disks $(10 \mathrm{~mm}$ diameter, $3 \mathrm{~mm}$ thick, hardness $190-210 \mathrm{HV}_{30}$, $\mathrm{Ra} \leq 0.02 \mu \mathrm{m}$ ) used as lower specimen. Coefficient of friction $(\mathrm{COF})$ and electrical contact resistance (ECR) were recorded during the tests and wear volume was measured on the disk's surface using confocal microscopy (Leica DCM 3D). Both specimens were cleaned with heptane in an ultrasonic bath during 5 minutes before tribological tests and also before worn surface characterization. After the cleaning process, both specimens were rinsed in ethanol and then airdried.

\subsection{Surface characterization}


After tribological tests worn surfaces were analyzed with a scanning electron microscope (SEM) in order non monochromatized $\mathrm{Al}$ radiation $(\mathrm{K}$ alpha $=1486.7 \mathrm{eV})$ at $13 \mathrm{kV}$ and $200 \mathrm{~W}$. Electromagnetic lenses were used in small area mode or high magnification in the case of iron and oxygen. Number of scans ranged from 10 to 40 according to the chemical elements content on the disk's surface in order to obtain high resolution spectra. Survey spectra were taken with $90 \mathrm{eV}$ pass energy and $1 \mathrm{eV}$ step energy (a single scan), whereas high resolution spectra were measured using $30 \mathrm{eV}$ pass energy and $0.1 \mathrm{eV}$ energy step. Curve fitting for high resolution XPS analysis is performed using a product $70 \%$ Gaussian-30\% Lorentzian shape curve and Shirley type baseline. In case that more than one curve is used for the fitting of a single element, full width at half maximum (fwhm) is constrained so as to all curves have the same fwhm value. In the case of Fe 2p3/2 fit, an exponential tail was considered for modelling the peaks of $\mathrm{Fe}(\mathrm{III})(\mathrm{T}=1.5)$ and $\mathrm{Fe}(0)(\mathrm{T}=0.65)$, as done by Mangolini et al. [57].

\section{Results and discussion}

\subsection{Tribological tests}

The base oil and the IL-containing mixtures showed unexpected friction behavior, Table 2. The average coefficient of friction of all tests was similar irrespective of both the lubricant sample and the load used. Similar behavior was found when this ionic liquid was tested as neat lubricant under different test conditions including those here used [18]. The study of the evolution of the coefficient of friction and electrical contact resistance (ECR) with time showed that the initial higher coefficient of friction values decrease with the increase of ECR probably due to the tribofilm formation, Fig. 1. The ECR values were higher at the lowest $(40 \mathrm{~N})$ and intermediate $(80 \mathrm{~N})$ loads, while at the highest $(120 \mathrm{~N})$ load they decreased. This behavior could be related to adsorption-desorption processes, which are temperature- and hence load-dependent.

The polar nature of the lubricant samples promotes a competition for the metallic surface between the base oil and the ionic liquid but it seems that the higher concentration of the base oil leads to abovementioned similar friction results [58]. Improved friction results were obtained when nonpolar base oils (mineral oils or polyalphaolefins) were used as main component in a binary mixture with polar compounds (esters or ionic liquids) [8, 33, 35, 36, 58-60]. Mixtures of nonpolar base oil and an ester were also used in the preparation of an emulsion for lubricant purposes resulting in improved tribological behavior [61]. 
Table 2. Average coefficient of friction and standard deviation for tests made with all samples.

\begin{tabular}{ccccccc}
\hline \multirow{2}{*}{$\begin{array}{c}\text { IL conc. } \\
(\text { wt \%) }\end{array}$} & \multicolumn{2}{c}{$\mathbf{4 0 ~ N}$} & \multicolumn{2}{c}{$\mathbf{8 0 ~ N}$} & \multicolumn{2}{c}{$120 \mathbf{~ N}$} \\
\cline { 2 - 7 } & Avg & SD $\left(\times 10^{-3}\right)$ & Avg & SD $\left(\times 10^{-3}\right)$ & Avg & SD $\left(\times 10^{-3}\right)$ \\
\hline 0.00 & 0.070 & 1.994 & 0.068 & 0.401 & 0.069 & 2.150 \\
1.25 & 0.069 & 1.665 & 0.068 & 0.665 & 0.068 & 0.480 \\
2.50 & 0.069 & 1.209 & 0.069 & 0.845 & 0.070 & 1.471 \\
3.75 & 0.071 & 3.150 & 0.068 & 0.842 & 0.070 & 0.701 \\
5.00 & 0.070 & 2.801 & 0.070 & 1.559 & 0.068 & 0.505 \\
\hline
\end{tabular}

a)

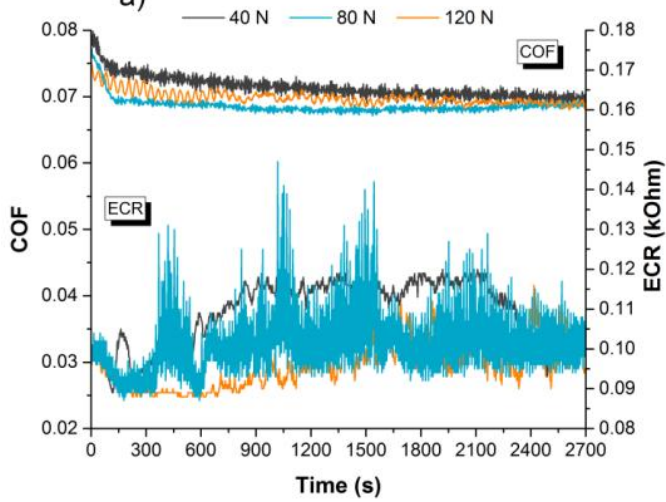

c)

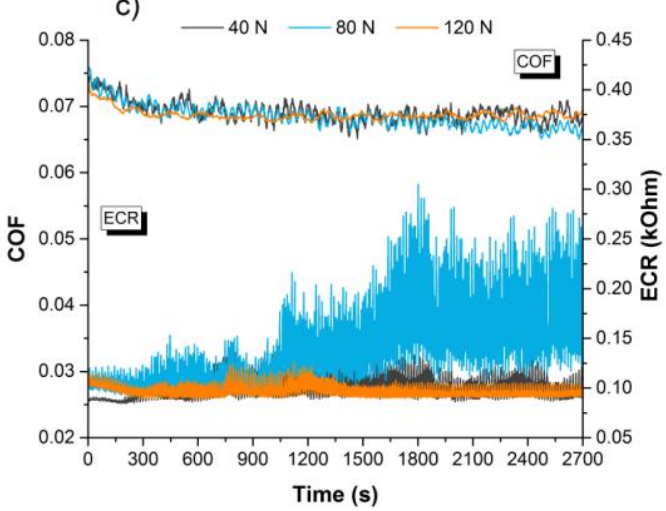

b)

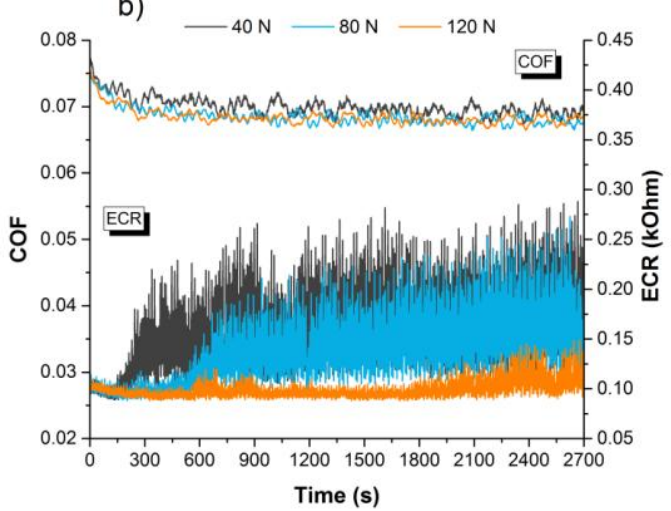

d)

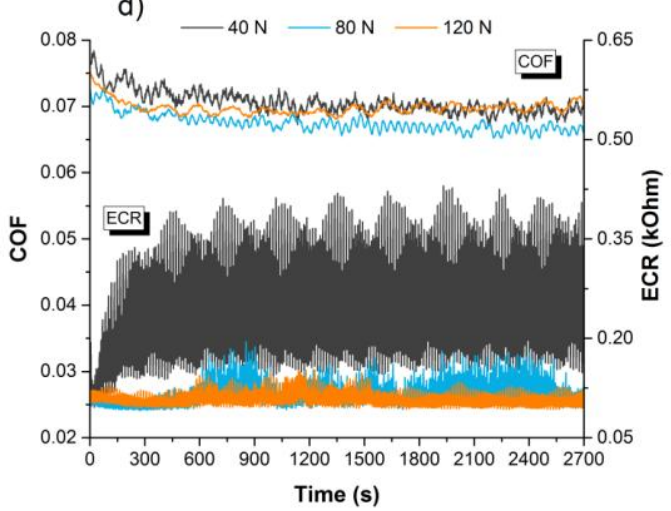

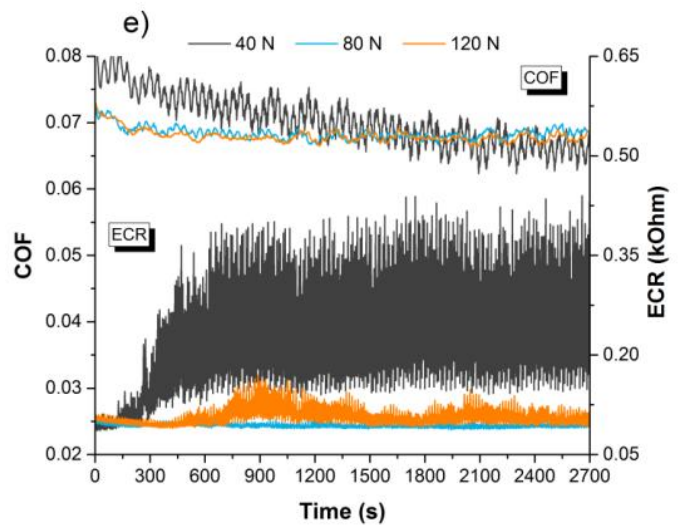

Fig. 1. Evolution with time of both the coefficient of friction and electrical contact resistance: a) $\mathrm{A} 2$ b) $\mathrm{A} 2+1.25 \mathrm{wt} \%$ IL c) $\mathrm{A} 2+2.50 \mathrm{wt} \%$ IL d) $\mathrm{A} 2+3.75 \mathrm{wt} \%$ IL e) $\mathrm{A} 2+5.00 \mathrm{wt} \% \mathrm{IL}$. 
The wear results were different under the three loads used and the IL concentration in the mixtures also influenced on them, Fig. 2. Wear reductions were found for all mixtures with regard to the base oil at 40 $\mathrm{N}$-load, with the highest wear reduction for the highest IL concentration (5.00 wt \%). On the other hand, a significant wear reduction with regard to the base oil was found at $80 \mathrm{~N}$-load for the mixtures containing $2.50 \mathrm{wt} \%$ of IL. Meanwhile, the mixtures containing $1.25 \mathrm{wt} \%$ of IL showed the highest wear reduction at 120 N-load. These different behaviors are not only related with adsorption-desorption processes but also with chemical reaction of the lubricant samples with worn surface. These possible chemical reactions were studied by X-ray spectroscopy (XPS) and their results are shown in the next section.
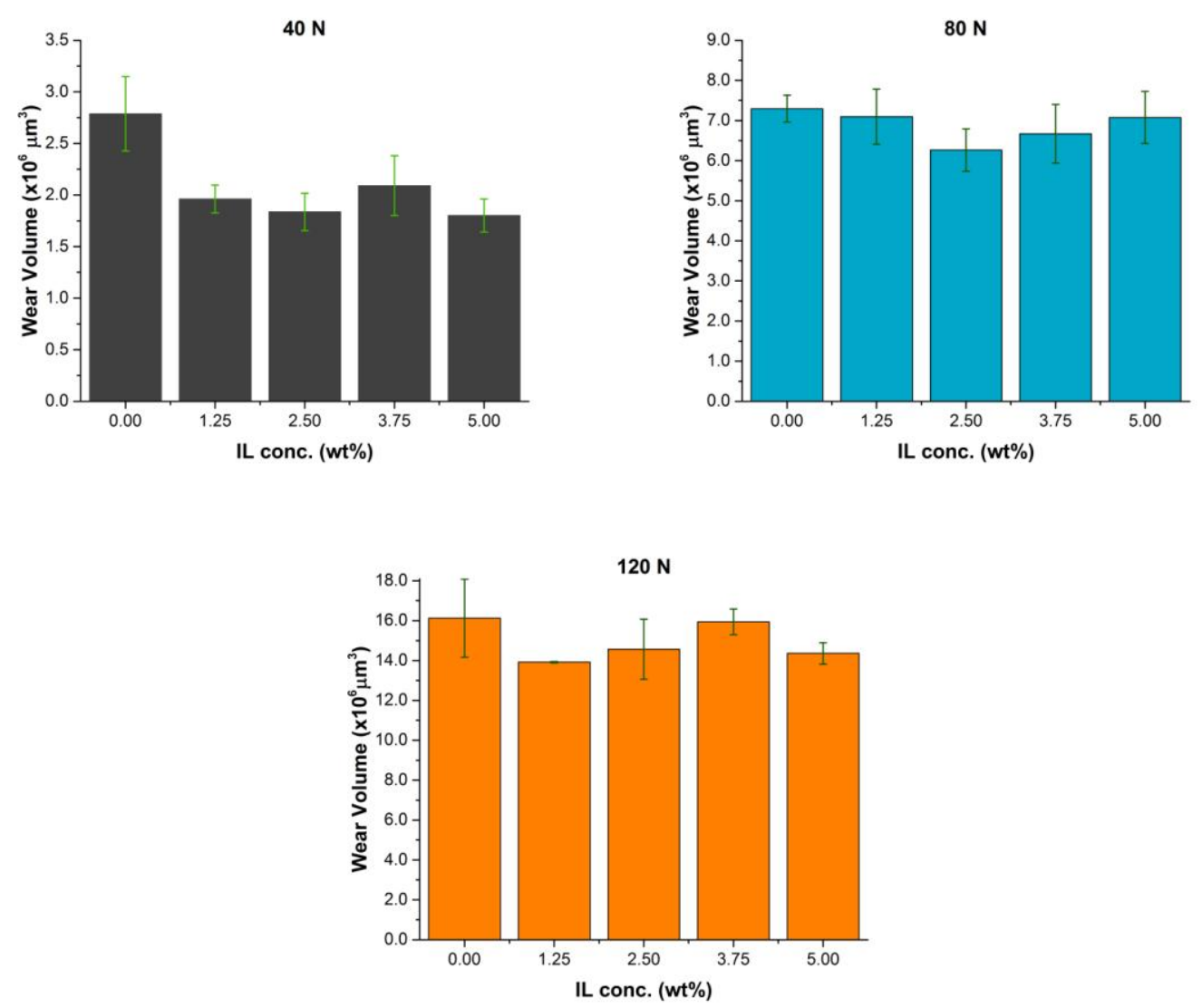

Fig. 2. Average wear volume and standard deviation for tests made with all samples.

\subsection{Worn surface characterization}

Fig. 3 shows the images of the worn surface on the disks (lower specimen) taken with scanning electron microscopy. An increase in wear scar width can be observed with the increase of the load. The predominant wear mechanism was adhesive for all lubricant samples under the three loads. The SEM images also show that the lowest surface damage at $40 \mathrm{~N}$-load was obtained with the mixture containing $5.00 \mathrm{wt} \%$ of IL; while at $80 \mathrm{~N}$ and $120 \mathrm{~N}$ the lowest surface damage was obtained with the mixtures at 2.50 and $1.25 \mathrm{wt} \%$ of IL, respectively. 


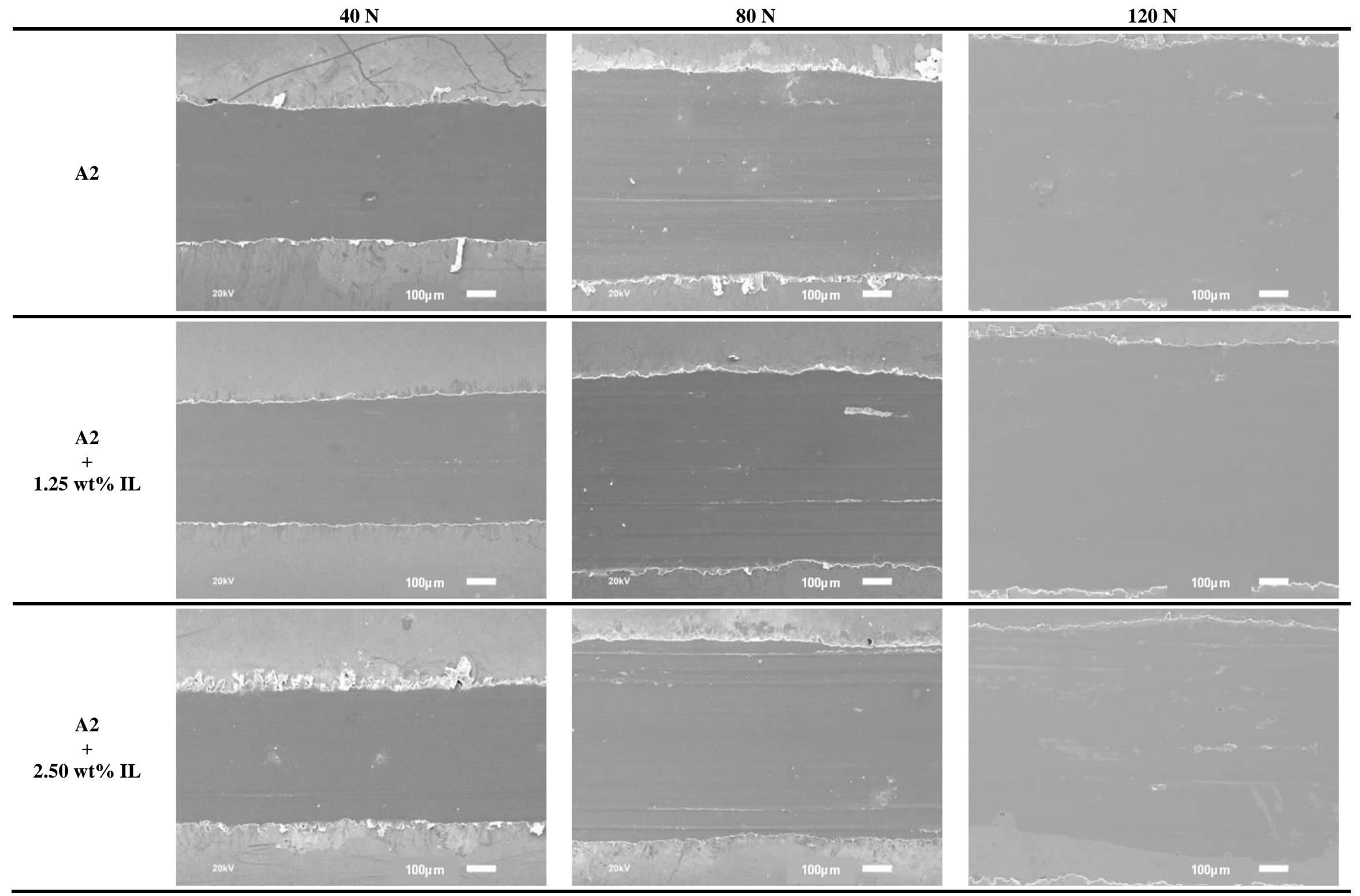




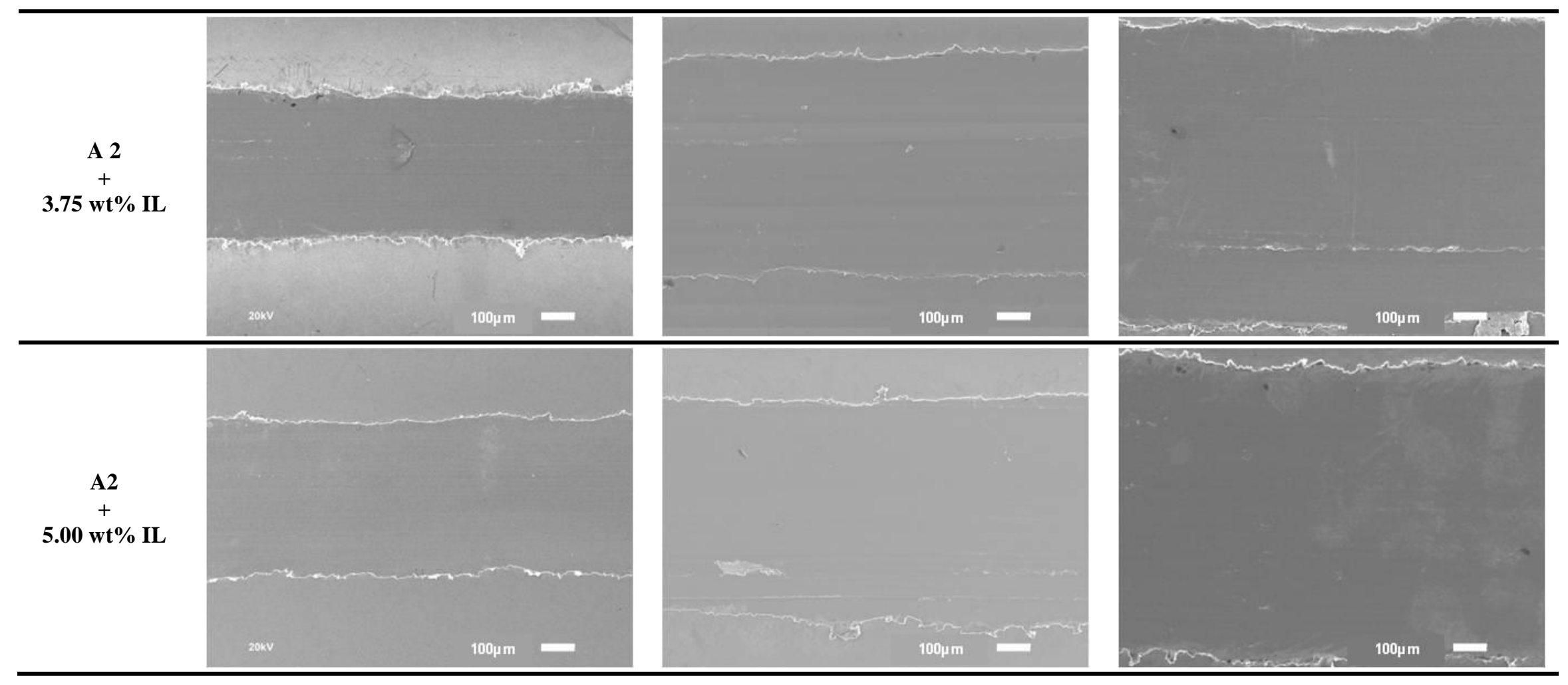

Fig. 3. SEM images from the wear surface on the disks after the tribological tests. 
The chemical analysis (EDS) of the wear surface at both lowest and highest load for the neat base oil and the mixture with the higher IL concentration showed similar results with the detection of only the elements present in the steel, Fig. 4. This result is close related to the fact that the EDS technique detects elements from a depth of microns, while the tribolayer formed by the interaction of lubricant samples and the surface should have a thickness of nanometers.

$40 \mathrm{~N}$

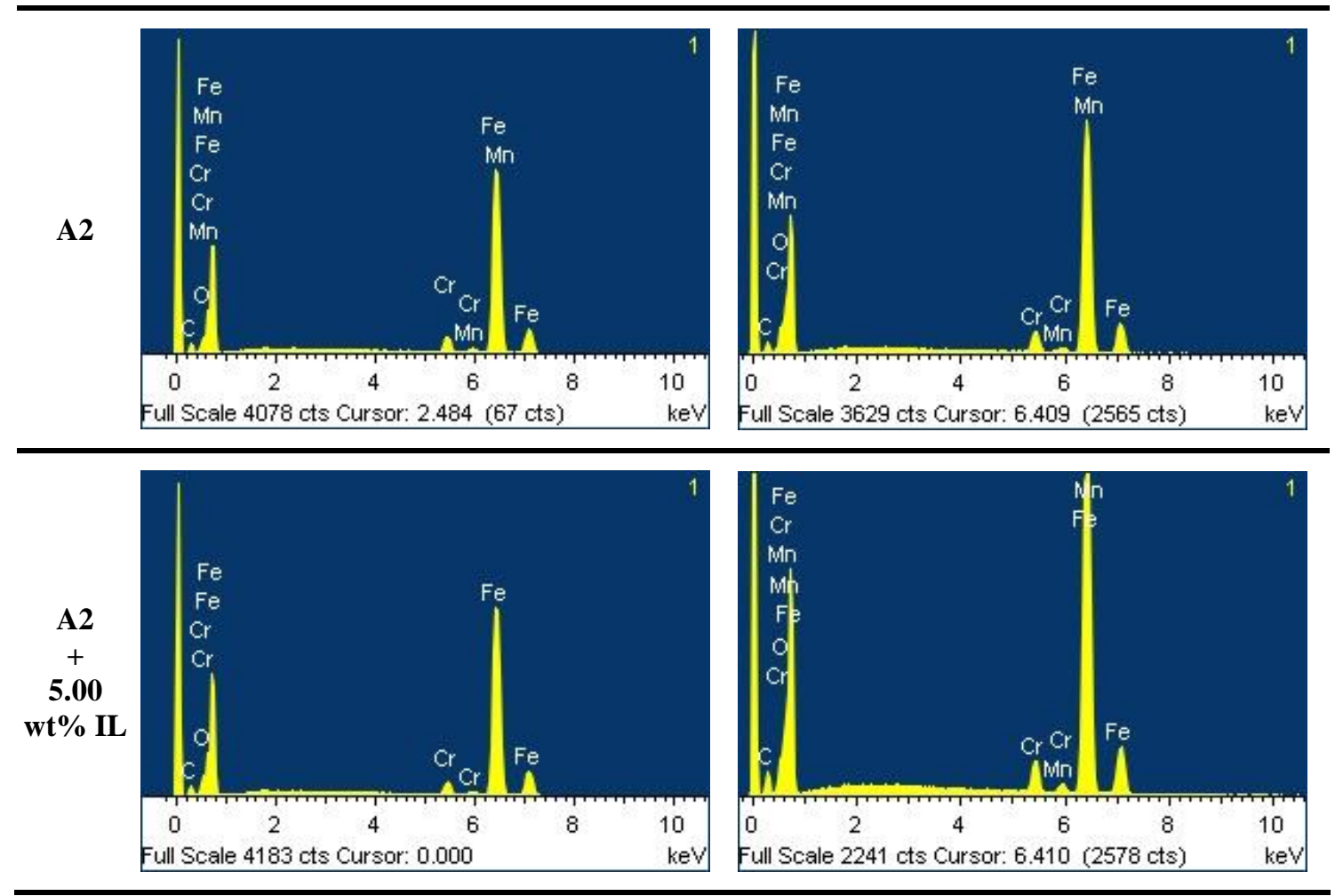

Fig. 4. EDS from the wear surface on the disks after the tribological tests. Concerning the $\mathrm{Fe} 2 \mathrm{p} 3 / 2$ analysis, three different species appear to be present: $\mathrm{Fe}(0)$ at $707.4 \pm 0.1 \mathrm{eV}, \mathrm{Fe}$ (III) at $710.5 \pm 0.1 \mathrm{eV}$ and $\mathrm{FeOOH}$ at $712.4 \pm 0.1 \mathrm{eV}[57,62]$. Fig. 5 shows the Fe 2p3/2 XPS band of the surface lubricated with neat A2, in absence of ionic liquid. There is no evident difference in the surfaces regardless the applied load. 

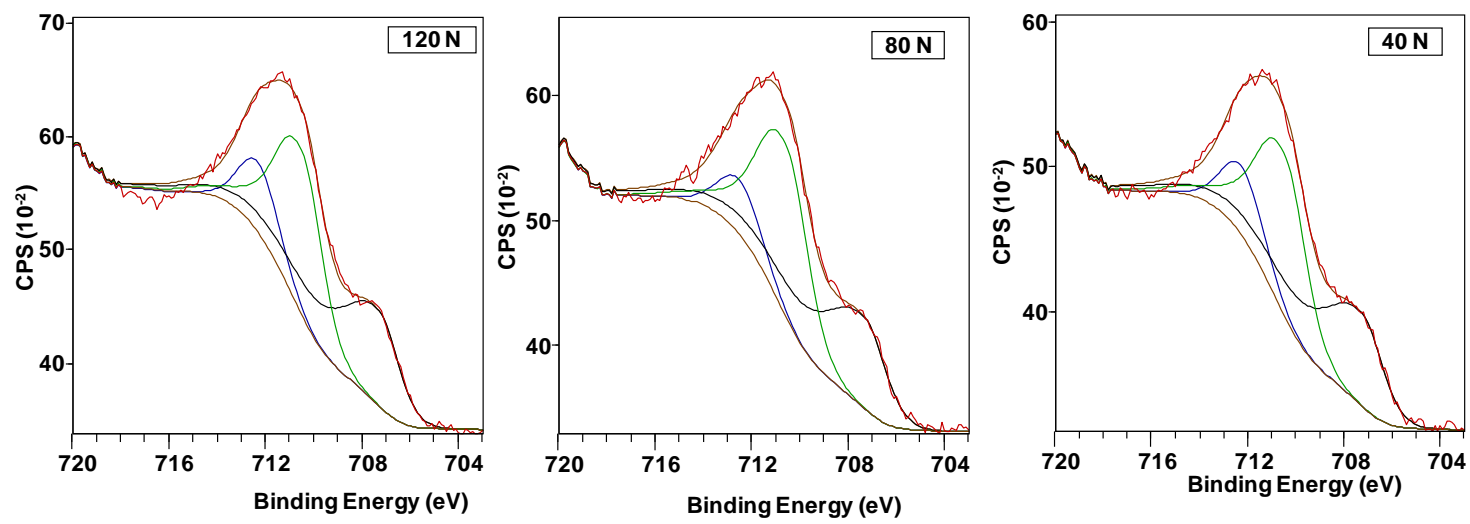

Fig. 5. Fe2p3/2 XPS band for samples lubricated with neat A2 at different loads.

Likewise, Fig. 6 records the XPS Fe2p3/2 band of the surfaces assayed at $120 \mathrm{~N}$ and lubricated with growing concentrations of ionic liquid. There is also any evidence of difference among these spectra, being the surfaces very similar with respect to iron. Taking into account the poor difference in the iron for these samples, further analysis concerning oxygen $(\mathrm{O} 1 \mathrm{~s})$ was carried out and shown in Fig. 7. The O1s spectrum in every sample can be fitted using two curves located at $532.7 \mathrm{eV}$ and $530.6 \mathrm{eV}$, usually associated to organic oxygen [23] and iron oxides [18]. However, the ratio $\mathrm{O}_{532.7} / \mathrm{O}_{530.6}$ is different for the sample without ionic liquid (0.58) from the others $(0.76 \pm 0.04$ as a mean value for samples with 1.25 , 2.50, 3.75 and $5.00 \mathrm{wt} \%$ of IL). This difference can arise either from a bigger amount of organic oxygen or from a reduction in the surface iron oxides, but the previously shown spectra of iron did not suggest differences in the iron oxides, being more likely that the higher $\mathrm{O}_{532.7} / \mathrm{O}_{530.6}$ ratio comes from the ionic liquid. 

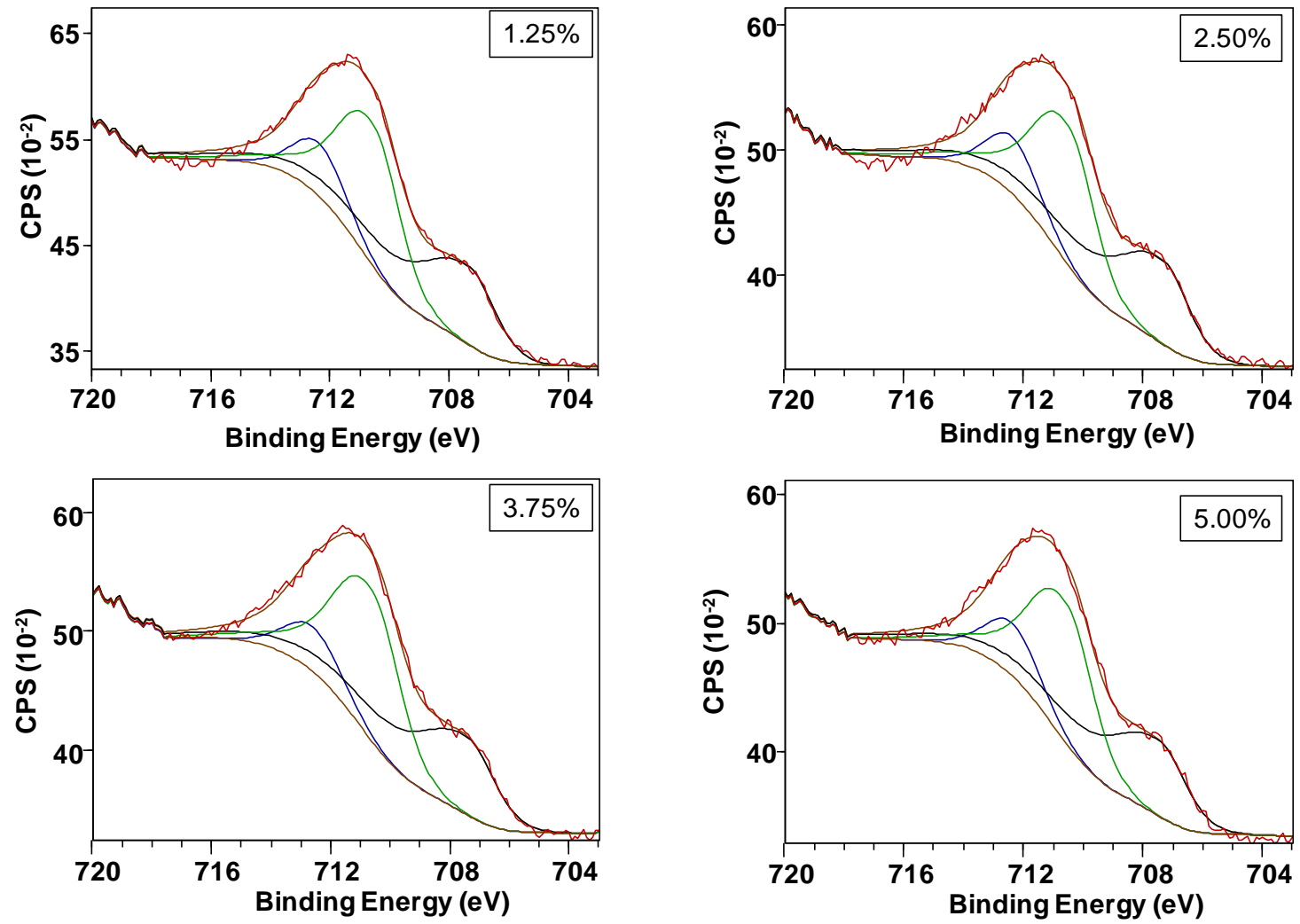

Fig. 6. Fe2p3/2 band for samples tested at $120 \mathrm{~N}$ with mixtures containing $1.25,2.50,3.75$ and $5.00 \mathrm{wt} \%$ of IL.
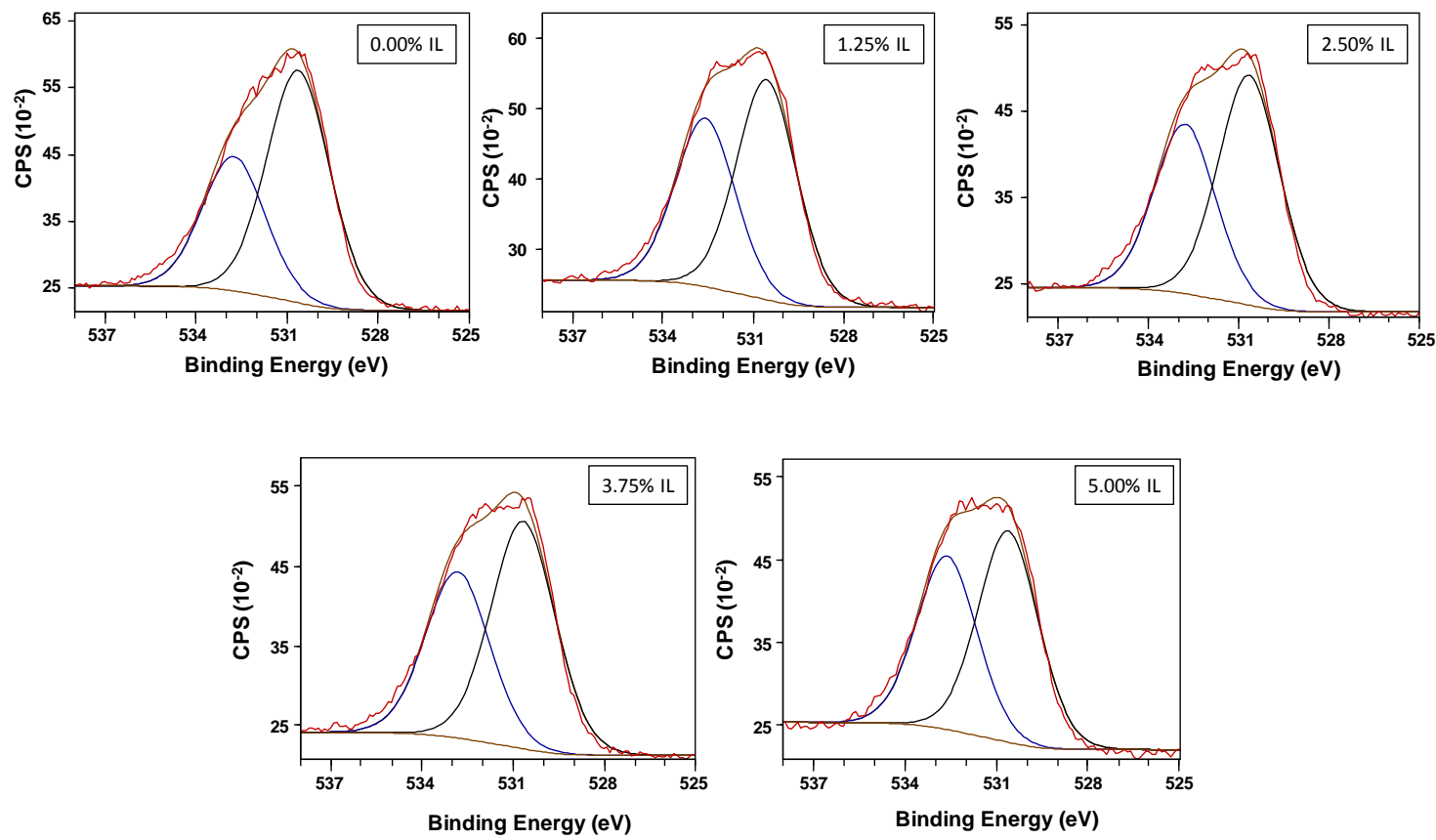

Fig. 7. O1s band for samples assayed at $120 \mathrm{~N}$ with ionic liquid concentration ranging 0-5.00 wt $\%$. 
The Fe2p3/2 XPS band of samples showing the lowest wear damage at different loads (1.25 wt $\%$ IL at $120 \mathrm{~N}, 2.50 \mathrm{wt} \% \mathrm{IL}$ at $80 \mathrm{~N}$ or $5.00 \mathrm{wt} \%$ IL at $40 \mathrm{~N}$ ) were also compared and shown in Fig. 8, with a scarce difference to the previously shown Fe spectra.
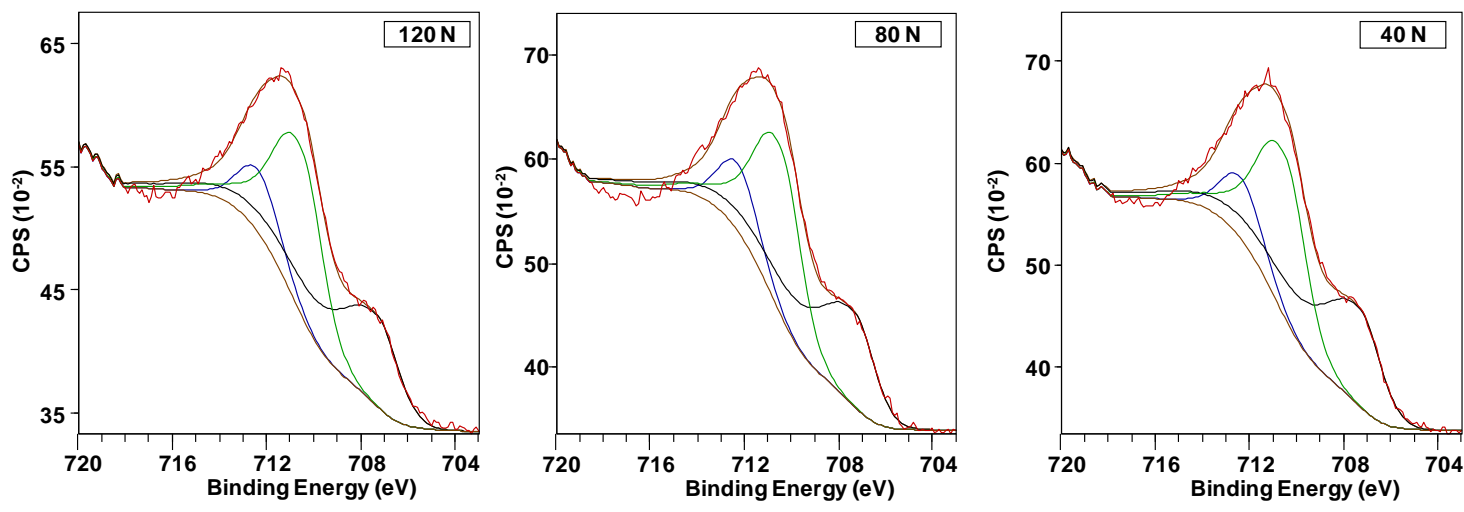

Fig. 8. Fe2p3/2 band for samples assayed at $120 \mathrm{~N}$ with $1.25 \mathrm{wt} \% \mathrm{IL}, 80 \mathrm{~N}$ with $2.50 \mathrm{wt} \%$ IL and $40 \mathrm{~N}$ with $5.00 \mathrm{wt} \%$ IL.

Finally, fluorine could only be clearly detected in samples lubricated with $5.00 \mathrm{wt} \%$ IL at 40 N, $2.50 \mathrm{wt} \%$ IL at $80 \mathrm{~N}$ and $2.50 \mathrm{wt} \% \mathrm{IL}$ at $120 \mathrm{~N}$, although there is also a very poor band in the case of $1.25 \mathrm{wt} \% \mathrm{IL}$ at $120 \mathrm{~N}$. These samples correspond to those with the lowest wear values according to Fig. 2. As it is shown in Fig. 9 (left), there is a clear F1s band centered at $689.5 \mathrm{eV}$ in the case of the samples assayed with $5.00 \mathrm{wt} \%$ of IL at $40 \mathrm{~N}$-load. The position of this band agrees with the expected value of $689.0 \mathrm{eV}$ for the $\left[\mathrm{NTf}_{2}\right]$ anion, according to the work by Bovio et al [63]. The same band can also be found for samples assayed at higher loads (80 and $120 \mathrm{~N})$ using a lower amount of ionic liquid (2.50 wt\%), as shown in Fig. 9 (center) and Fig. 9 (right). These results agree with those with lowest wear volumes, which have more evident presence of fluorine on the surface. 

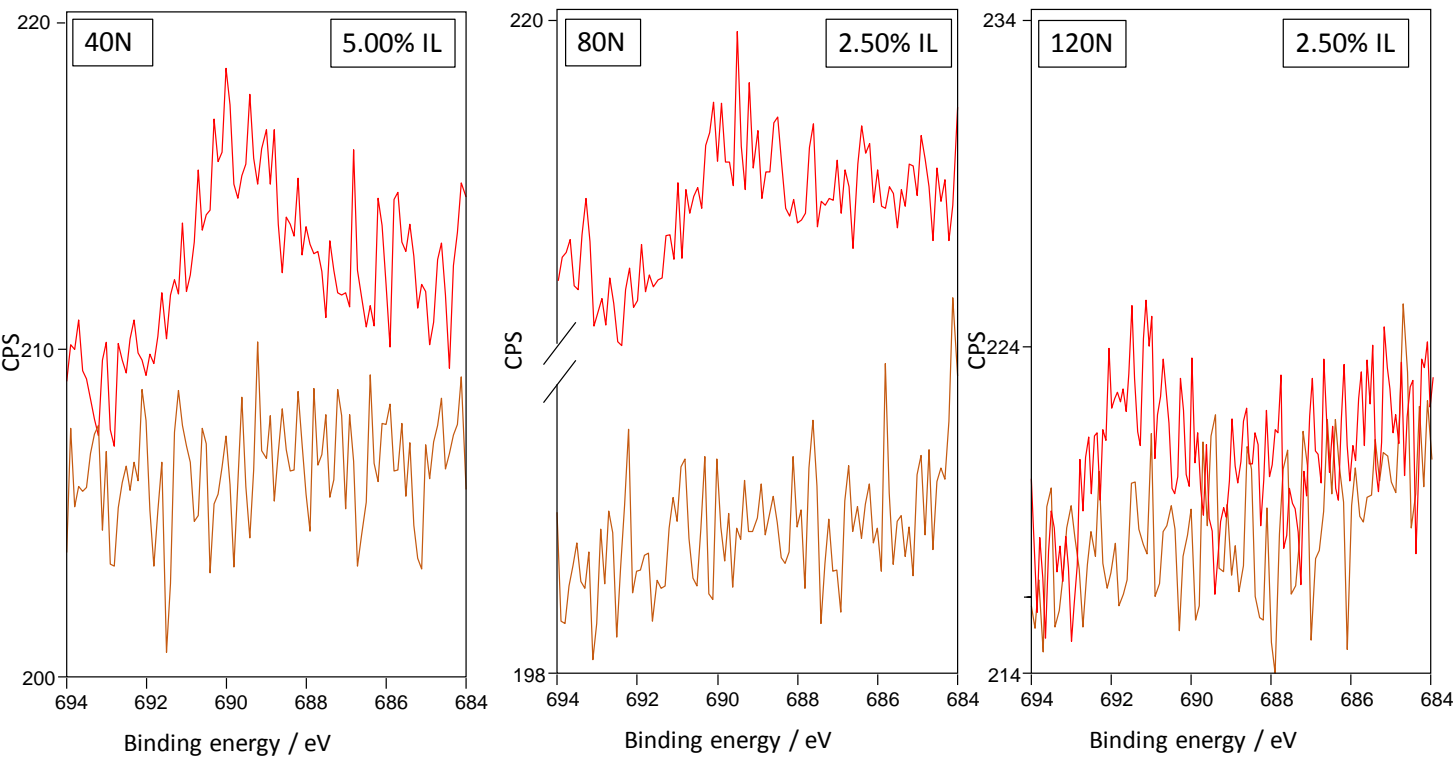

Fig. 9. F1s band for samples assayed at $40 \mathrm{~N}$ and $5.00 \mathrm{wt} \% \mathrm{IL}$ (left), $80 \mathrm{~N}$ and $2.50 \mathrm{wt} \% \mathrm{IL}$ (center), and $120 \mathrm{~N}$ and $2.50 \mathrm{wt} \% \mathrm{IL}$ (right).

\section{Conclusions}

An ammonium cation-based IL was used as an additive at different concentrations in a polar oil in order to study both friction and wear reduction properties of the IL and possible interferences of the base oil on those properties due to its polar nature. The following conclusions can be drawn from the results obtained:

- The base oil and all the mixtures showed similar friction results, which can be related to the similar polar nature of the base oil and the IL, resulting in a competition of both for the surface.

- Wear results were different with increasing values when load increased, meanwhile wear reduction of the mixtures with regard to the neat base oil was different for each IL concentration under the three loads. The different wear behavior of the mixtures could be related to the adsorption-desorption processes, which are both temperature and load dependent.

- The chemical analysis of the worn surface by EDS did not show differences. On the other hand, the XPS analysis showed similar results for the chemical state of iron, which probably influenced on the similar coefficient of friction showed by all lubricant samples. However, fluorine was found on the worn surface with the lowest wear volumes, and the corresponding binding energy is consistent with the presence of the $\left[\mathrm{NTf}_{2}\right]$ anion. 


\section{Acknowledgments}

The authors want to thank to the Ministry of Economy and Competitiveness (Spain) and FICYT (Foundation for the Promotion in Asturias of the Applied Scientific Research and Technology) for supporting this work under the research projects STARLUBE (DPI2013-48348-C2-1-R) and Lubrication and Surface Technology (GRUPIN14-023), respectively. The Scientific-Technical Services at the University of Oviedo are also acknowledged.

\section{References}

1. Ye C, Liu W, Chen Y, Yu L. Room-temperature ionic liquids: a novel versatile lubricant. Chem Commun (Camb) 2001:2244-5. doi:10.1039/B106935G.

2. Minami I. Ionic liquids in tribology. Molecules 2009;14:2286-305. doi:10.3390/molecules14062286.

3. Bermúdez MD, Jiménez AE, Sanes J, Carrión FJ. Ionic liquids as advanced lubricant fluids. Molecules 2009;14:2888-908. doi:10.3390/molecules14082888.

4. Palacio M, Bhushan B. A review of ionic liquids for green molecular lubrication in nanotechnology. Tribol Lett 2010;40:247-68. doi:10.1007/s11249-010-9671-8.

5. Somers A, Howlett P, MacFarlane D, Forsyth M. A Review of Ionic Liquid Lubricants. Lubricants 2013;1:3-21. doi:10.3390/lubricants1010003.

6. Zhou Y, Qu J. Ionic liquids as lubricant additives: a review. ACS Appl. Mater. Interfaces 2017;94:3209-22. doi: 10.1021/acsami.6b12489.

7. Jiménez AE, Bermúdez MD, Iglesias P, Carrión FJ, Martínez-Nicolás G. 1-N-alkyl -3methylimidazolium ionic liquids as neat lubricants and lubricant additives in steel-aluminium contacts. Wear 2006;260:766-82. doi:10.1016/j.wear.2005.04.016.

8. Qu J, Blau PJ, Dai S, Luo H, Meyer HM. Ionic liquids as novel lubricants and additives for diesel engine applications. Tribol Lett 2009;35:181-9. doi:10.1007/s11249-009-9447-1.

9. Zhang L, Feng D, Xu B. Tribological characteristics of alkylimidazolium diethyl phosphates ionic liquids as lubricants for steel-steel contact. Tribol Lett 2009;34:95-101. doi:10.1007/s11249-0099412-z.

10. Jiang D, Hu L, Feng D. Crown-type ionic liquids as lubricants for steel-on-steel system. Tribol Lett 2011;41:417-24. doi:10.1007/s11249-010-9726-x. 
11. Somers AE, Biddulph SM, Howlett PC, Sun J, MacFarlane DR, Forsyth M. A comparison of phosphorus and fluorine containing IL lubricants for steel on aluminium. Phys Chem Chem Phys 2012;14:8224. doi:10.1039/c2cp40736a.

12. Totolin V, Minami I, Gabler C, Dörr N. Halogen-free borate ionic liquids as novel lubricants for tribological applications. Tribol Int 2013;67:191-8. doi:10.1016/j.triboint.2013.08.002.

13. Hernández Battez A, González R, Viesca JL, Fernández-González A, Hadfield M. Lubrication of PVD coatings with ethyl-dimethyl-2-methoxyethylammonium tris(pentafluoroethyl)trifluorophosphate. $\quad$ Tribol $\quad$ Int 2013;58:71-8. doi:10.1016/j.triboint.2012.10.001.

14. Otero I, López ER, Reichelt M, Fernández J. Friction and anti-wear properties of two tris(pentafluoroethyl) trifluorophosphate ionic liquids as neat lubricants. Tribol Int 2014;70:104-11. doi:10.1016/j.triboint.2013.10.002.

15. García A, González R, Hernández Battez A, Viesca JL, Monge R, Fernández-González A, Hadfield M. Ionic liquids as a neat lubricant applied to steel-steel contacts. Tribol Int 2014;72:42-50. doi:10.1016/j.triboint.2013.12.007.

16. Mahrova M, Pagano F, Pejakovic V, Valea A, Kalin M, Igartua A, Tojo E. Pyridinium based dicationic ionic liquids as base lubricants or lubricant additives. Tribol Int 2015;82:245-54. doi:10.1016/j.triboint.2014.10.018.

17. Hernández Battez A, Bartolomé M, Blanco D, Viesca JL, Fernández-González A, González R. Phosphonium cation-based ionic liquids as neat lubricants: Physicochemical and tribological performance. Tribol Int 2016;95:118-31. doi:10.1016/j.triboint.2015.11.015.

18. Hernández Battez A, Blanco D, Fernández-González A, Mallada MT, González R, Viesca JL. Friction, wear and tribofilm formation with a $\left[\mathrm{NTf}_{2}\right]$ anion-based ionic liquid as neat lubricant. Tribol Int 2016;103:73-86. doi: 10.1016/j.triboint.2016.06.038.

19. Qu J, Truhan JJ Jr, Dai S, Luo H, Blau PJ. Ionic Liquids with ammonium cations as lubricants or additives. Tribol Lett 2006;22:207-14. doi: 10.1007/s11249-006-9081-0.

20. Qu J, Truhan JJ Jr, Dai S, Luo H, Blau PJ. Lubricants or lubricant additives composed of ionic liquids containing ammonium cations. U.S. Patent 7,754,664, Jul. 13, 2010. 
21. Blanco D, González R, Hernández Battez A, Viesca JL, Fernández-Gonzlez A. Use of ethylthe lubrication of TiN PVD coating. Tribol Int 2011;44:645-50. doi: 10.1016/j.triboint.2011.01.004.

22. Blanco D, Battez AH, Viesca JL, González R, Fernández-González A. Lubrication of CrN coating with ethyl-dimethyl-2-methoxyethylammonium tris(pentafluoroethyl)trifluorophosphate ionic liquid as additive to PAO 6. Tribol Lett 2011;41:295-302. doi: 10.1007/s11249-010-9714-1.

23. Gonzalez R, Battez AH, Viesca JL, Higuera-Garrido A, Fernandez-Gonzalez A. Lubrication of DLC coatings with two tris(pentafluoroethyl)trifluorophosphate anion-based ionic liquids. Tribol Trans 2013;56:887-95. doi: 10.1080/10402004.2013.810319.

24. Viesca JL, Garcia A, Hernandez Battez A, Gonzalez R, Monge R, Fernandez-Gonzalez A, Hadfield M. FAP- anion ionic liquids used in the lubrication of a steel-steel contact. Tribol Lett 2013;52: 431-37. doi: 10.1007/s11249-013-0226-7.

25. Battez AH, Gonzalez R, Viesca JL, Blanco D, Asedegbega E, Osorio A. Tribological behaviour of two imidazolium ionic liquids as lubricant additives for steel/steel contacts. Wear 2009;266: 1224-28. doi: 10.1016/j.wear.2009.03.043.

26. Gonzalez R, Hernandez Battez A, Blanco D, Viesca JL, Fernandez-Gonzalez A. Lubrication of TiN, CrN and DLC PVD Coatings with 1-Butyl-1-Methylpyrrolidinium Tris(Pentafluoroethyl)Trifluorophosphate. Tribol Lett 2010;40:269-77. doi: 10.1007/s11249-010-9674-5.

27. Qu J, Bansal DG, Yu B, Howe JY, Luo HM, Dai S, Li HQ, Blau PJ, Bunting BG, Mordukhovich G, Smolenski DJ. Antiwear performance and mechanism of an oil-miscible ionic liquid as a lubricant additive. ACS Appl Mater Interfaces 2012;4:997-1002. doi: 10.1021/am201646k.

28. Zhou Y, Dyck J, Graham TW, Luo HM, Leonard DN, Qu J. Ionic liquids composed of phosphonium cations and organophosphate, carboxylate, and sulfonate anions as lubricant additives. Langmuir 2014;30:13301-11. doi: 10.1021/la5032366.

29. Westerholt A, Weschta M, Boesmann A, Tremmel S, Korth Y, Wolf M, Schluecker E, Wehrum N, Lennert A, Uerdingen M, Holweger W, Wartzack S, Wasserscheid P. Halide- free synthesis and tribological performance of oil-miscible ammonium and phosphonium-based ionic liquids. ACS Sustainable Chem. Eng. 2015;3:797-808. doi: 10.1021/sc500517n.

30. Sharma V, Doerr N, Aswath PB. Chemical-mechanical properties of tribofilms and their relationship to ionic liquid chemistry. RSC Adv 2016;6:22341-56. doi: 10.1039/c6ra01915c. 
31. Qu J, Luo HM, Chi MF, Ma C, Blau PJ, Dai S, Viola MB. Comparison of an oil-miscible ionic liquid and ZDDP as a lubricant anti-wear additive. Tribol Int 2014;71:88-97. doi: 10.1016/j.triboint.2013.11.010.

32. González R, Bartolomé M, Blanco D, Viesca JL, Fernández-González A, Battez AH. Effectiveness of phosphonium cation-based ionic liquids as lubricant additive. Tribol Int 2016;98:82-93. doi: 10.1016/j.triboint.2016.02.016.

33. Somers AE, Khemchandani B, Howlett PC, Sun JZ, MacFarlane DR, Forsyth M. Ionic Liquids as antiwear additives in base oils: Influence of structure on miscibility and antiwear performance for steel on aluminum. ACS Appl Mater Interfaces 2013;5:11544-53. doi: 10.1021/am4037614.

34. Sharma V, Gabler C, Doerr N, Aswath PB. Mechanism of tribofilm formation with $\mathrm{P}$ and $\mathrm{S}$ containing ionic liquids. Tribol Int 2015;92:353-64. doi: 10.1016/j.triboint.2015.07.009.

35. Hernández Battez A, Fernandes CMCG, Martins RC, Bartolomé M, González R, Seabra JHO. Two phosphonium cation-based ionic liquids used as lubricant additive: Part I: Film thickness and friction characteristics. Tribol Int 2017;107:233-9. doi: 10.1016/j.triboint.2016.10.048.

36. Hernández Battez A, Fernandes CMCG, Martins RC, Graça BM, Anand M, Blanco D, Seabra JHO. Two phosphonium cation-based ionic liquids used as lubricant additive. Part II: Tribofilm analysis and friction torque loss in cylindrical roller thrust bearings at constant temperature. Tribol Int 2017;109:496-504. doi: 10.1016/j.triboint.2017.01.020.

37. Jimenez AE, Bermudez MD. Imidazolium Ionic liquids as additives of the synthetic ester propylene glycol dioleate in aluminium-steel lubrication. Wear 2008;265:787-798. doi: 10.1016/j.wear.2008.01.009.

38. Yao MH, Liang YM, Xia YQ, Zhou F. Bisimidazolium ionic liquids as the high-performance antiwear additives in Poly(Ethylene Glycol) for steel-steel contacts. ACS Appl. Mater. Interfaces 2009;1:467-71. doi: 10.1021/am800132z.

39. Cai MR, Liang YM, Yao MH, Xia YQ, Zhou F, Liu WM. Imidazolium ionic liquids as antiwear and antioxidant additive in Poly(Ethylene Glycol) for steel/steel contacts. ACS Appl Mater Interfaces 2010;2:870-876. doi: 10.1021/am900847j.

40. Kronberger M, Pejakovic V, Gabler C, Kalin M. How anion and cation species influence the tribology of a green lubricant based on ionic liquids. Proc Inst Mech Eng, Part J 2012;226: 933-951. doi: $10.1177 / 1350650112459012$. 
41. Pejakovic V, Kronberger M, Mahrova M, Vilas M, Tojo E, Kalin M. Pyrrolidinium sulfate and ammonium sulfate ionic liquids as lubricant additives for steel/steel contact lubrication. Proc Inst Mech Eng, Part J 2012;226:923-932. doi: 10.1177/1350650112448978.

42. Jiménez AE, Bermúdez MD. Short alkyl chain imidazolium ionic liquid additives in lubrication of three aluminium alloys with synthetic ester oil. Tribol-Mater, Surf Interfaces 2012;6:109-115. doi: 10.1179/1751584X12Y.0000000011.

43. Otero I, Lopez ER, Reichelt M, Villanueva M, Salgado J, Fernandez J. Ionic liquids based on phosphonium cations as neat lubricants or lubricant additives for a steel/steel contact. ACS Appl Mater Interfaces 2014;6:13115-28. doi: 10.1021/am502980m.

44. Khemchandani B, Somers A, Howlett R, Jaiswal AK, Sayanna E, Forsyth M. A biocompatible ionic liquid as an antiwear additive for biodegradable lubricants. Tribol Int 2014;77:171-77. doi: 10.1016/j.triboint.2014.04.016.

45. Gusain $\mathrm{R}, \quad$ Gupta $\mathrm{P}, \quad$ Saran $\mathrm{S}, \quad$ Khatri $\mathrm{OP}$ Halogen-free bis(imidazolium)/bis(ammonium)di[bis(salicylato)borate] ionic liquids as energy-efficient and environmentally friendly lubricant additives. ACS Appl Mater Interfaces 2014;6:15318-28. doi: 10.1021/am503811t.

46. Qiao D, Wang HZ, Feng DP. Tribological performance and mechanism of phosphate ionic liquids as additives in three base oils for steel-on-aluminum contact. Tribol Lett 2014;55:517-31. doi: 10.1007/s11249-014-0377-1.

47. Gusain R, Khatri OP. Halogen-free ionic liquids: effect of chelated orthoborate anion structure on their lubrication properties. RSC Adv 2015;5:25287-94. doi: 10.1039/c5ra03092g.

48. Gusain R, Dhingra S, Khatri OP. Fatty-acid-constituted halogen-free ionic liquids as renewable, environmentally friendly, and high-performance lubricant additives. Ind Eng Chem Res 2016;55:856-65. doi: 10.1021/acs.iecr.5b03347.

49. Cai MR, Liang YM, Zhou F, Liu WM. A novel imidazolium salt with antioxidation and anticorrosion dual functionalities as the additive in poly(ethylene glycol) for steel/steel contacts. Wear 2013;306:197-208. doi: 10.1016/j.wear.2012.09.001.

50. Zhu L, Zhao Q, Wu X, Zhao G, Wang X. A novel phosphate ionic liquid plays dual role in synthetic ester oil: from synthetic catalyst to anti-wear additive. Tribol Int 2016;97:192-199. doi: 10.1016/j.triboint.2015.12.047. 
51. Pejaković V, Tomastik C, Dörr N, Kalin M. Influence of concentration and anion alkyl chain length on tribological properties of imidazolium sulfate ionic liquids as additives to glycerol in steel-steel contact lubrication. Tribol Int 2016;97:234-243. doi: 10.1016/j.triboint.2016.01.034.

52. Yu B, Bansal DG, Qu J, Sun XQ, Luo HM, Dai S, Blau PJ, Bunting BG, Mordukhovich G, Smolenski DJ. Oil-miscible and non-corrosive phosphonium-based ionic liquids as candidate lubricant additives. Wear 2012;289:58-64. doi: 10.1016/j.wear.2012.04.015.

53. Monge R, González R, Hernández Battez A, Fernández-González A, Viesca JL, García A, Hadfield M. Ionic liquids as an additive in fully formulated wind turbine gearbox oils. Wear 2015;328329:50-63. doi: 10.1016/j.wear.2015.01.041. doi: 10.1016/j.wear.2015.01.041.

54. Fernandes CMCG, Battez AH Gonzalez R, Monge R, Viesca JL, Garcia A, Martins RC, Seabra JHO. Torque loss and wear of FZG gears lubricated with wind turbine gear oils using an ionic liquid as additive. Tribol Int 2015;90:306-14. doi: 10.1016/j.triboint.2015.04.037.

55. Anand M, Hadfield M, Viesca JL, Thomas B, Hernández Battez A, Austen S. Ionic liquids as tribological performance improving additive for in-service and used fully-formulated diesel engine lubricants. Wear 2015;334-335:67-74. doi: 10.1016/j.wear.2015.01.055.

56. Blanco D, Viesca JL, Mallada MT, Ramajo B, González R, , Hernández Battez A. Wettability and corrosion of [NTf2] anion-based ionic liquids on steel and PVD (TiN, CrN, ZrN) coatings. Surf Coat Tech 2016;302:13-21. doi: 10.1016/j.surfcoat.2016.05.051.

57. Mangolini F, Rossi A, Spencer ND. Influence of metallic and oxidized iron/steel on the reactivity of triphenyl phosphorothionate in oil solution. Tribol Int 2011;670:683-44. doi: 10.1016/j.triboint.2010.02.009.

58. Blanco D, González R, Viesca JL, Fernández-González A, Bartolomé M, Hernández Battez A. Antifriction and antiwear properties of an ionic liquid with fluorine-containing anion used as lubricant additive. Tribol Lett 2017;65:66. doi: 10.1007/s11249-017-0846-4.

59. Fernández Rico JE, Hernández Battez A, García Cuervo D. Wear prevention characteristics of binary oil mixtures. Wear 2002;253:827-31. doi: 10.1016/S0043-1648(02)00229-6.

60. Fan MJ, Yang DS, Wang XL, Liu WM, Fu HZ. DOSS- based QAILs: as both neat lubricants and lubricant additives with excellent tribological properties and good detergency. Ind Eng Chem Res 2014;53:17952-60. doi: 10.1021/ie502849w. 
61. Cambiella A, Benito JM, Pazos C, Coca J, Hernández A, Fernández JE. Formulation of emulsifiable cutting fluids and extreme pressure behaviour. J Mater Process Technol 2007;184:139-45. doi: 10.1016/j.jmatprotec.2006.11.014.

62. Mayer, T. Black spots on carbon steel after contact to lubricating oil with extreme pressure additives: an XPS study. Appl Surf Sci 2001;257:262-179. doi: 10.1016/S0169-4332(01)00292-6.

63. Bovio S, Podesta A, Lenardi C, Milani P. J Phys Chem B 2009;113:6600-3. http://dx.doi.org/10.1021/jp9022 